ELORE (ISSN 1456-3010), vol. $16-1 / 2009$.

Julkaisija: Suomen Kansantietouden Tutkijain Seura ry.

[http://www.elore.fi/arkisto/1_09/kirjat_mahlamaki2_01_09.pdf]

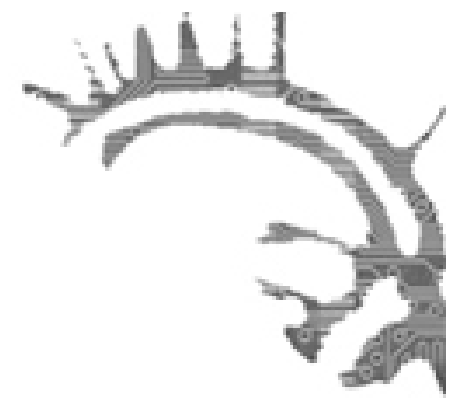

KIRJA-ARVIO:

\title{
NÄKÖKULMIA NYKYKULTTUURIN TUTKIMUKSEEN
}

Vainikkala, Erkki \& Mikkola, Henna (toim.) 2007: Nykyaika kulttuurintutkimuksessa. Nykykulttuurin tutkimuskeskuksen julkaisuja 86. Jyväskylä: Nykykultturin tutkimuskeskus. 351 sivua.

\section{Tiina Mahlamäki}

Viivästykset julkaisuprosessissa aiheuttivat sen, että vuonna 2007 julkaistuksi ilmoitettu teos tuli lukijoiden käsiin vasta vuoden 2008 jälkipuoliskolla. Nykyaika kulttuurintutkimuksessa -teosta voidaan pitää jatko-osana ainakin kahdelle aiemmin ilmestyneelle teokselle. Kulttuurintutkimus. Johdanto ilmestyi jo vuonna 1994 ja sen näkemys kulttuurintutkimuksesta läheni sitä, mitä nimitetään kulttuurien tutkimukseksi. Se kattoi alleen niin perinteentutkimuksen, folkloristiikan kuin antropologiankin. Nyt arvioitava teos sitoutuu birminghamilaiseen cultural studies -tutkimusperinteeseen tai oikeastaan sen perintönä syntyneisiin erilaisiin tutkimussuuntauksiin ja -painotuksiin. Läheisempi yhteys sillä onkin sen edeltäjään samassa Nykykulttuurin tutkimuskeskuksen julkaisusarjassa, teokseen Tutkimusten maailma. Suomalaista kulttuurintutkimusta kartoittamassa. Teos ilmestyi vuonna 2006 professori Mikko Lehtosen juhlakirjana ja siinä korostetaan kulttuurintutkimuksen kriittisyyttä ja yhteiskunnallisuutta, mikä ymmärretään erityisesti tutkijan osallisuutena tutkimaansa maailmaan. Nykyaika-teos on toki edeltäjäänsä kohdennetumpi, vaikka senkin käsittelemät aiheet ja esiin nostamat lähestymistavat haarautuvat moniaalle. Artikkeleita kerrotaan yhdistävän "kulttuurintutkimuksellinen ote ja kiinnostus kulttuurin monimuotoisuuteen meillä ja muualla", eli teos on rajattu melko löyhästi. Johdantoartikkelissa tämän oppikirjaksi tarkoitetun teoksen tehtäväksi kerrotaan "johdattaa erilaisiin tutkimusalueisiin, ilmiöihin, problematiikkoihin ja teoriasuuntauksiin, joissa kulttuuriulottuvuus on tärkeä”.

Rakenteellisesti artikkelikokoelma on jaettu kolmeen osioon. "Kohdennuksia"osassa esitellään erilaisia tutkimusotteita, kun taas "Kokemuksia ja käytäntöjä" -osiossa puolestaan erilaisia tutkimusaiheita. Tämä jaottelu ei kyllä osu aivan kohdalleen. Kolmas osio, nimeltään "Mihin tästä", sisältää vain yhden tekstin, kulttuurintutkimuksen gurun, Lawrence Grossbergin laajan katsauksen kulttuurintutkimuksen tulevaisuuteen. 


\section{NäKÖKULMiA NYKYKULtTUURIN TUTKIMUKSEEN}

Kustannustehokkaan lukijan tarpeisiin - tai teoksen oppikirjakäyttöä tukemaan - on teoksen johdantoluvussa kuvattu erittäin perusteellisesti kaikkien artikkelien keskeinen sisältö. Opiskelijoita se auttaa hahmottamaan artikkelien keskeiset pointit ja varttuneemmalle lukijalle se antaa hyvät eväät valita, mikä tai mitkä artikkelit häntä itseään kiinnostavat tai parhaiten hyödyttävät.

\section{KOHDENNUKSIA}

"Kohdennuksia"-osasto johdattaa lukijat kulttuurintutkimuksen erilaisiin tutkimusotteisiin: aikalaisdiagnostiikkaan, digitaalisen kulttuurin tutkimukseen, vastakulttuurin tutkimukseen, feministiseen ja postkolonialistiseen tutkimusotteeseen sekä reseptiotutkimukseen. Ensinnä Kimmo Jokinen esittelee sosiologisen kulttuurintutkimuksen pyrkimyksiä, tapoja ja mahdollisuuksia analysoida meneillään olevaa aikakautta, tehdä aikalaisdiagnoosia. Erityisen huomion kohteeksi nousee 2000-luvun tunnetuin diagnoosi, joka sirpaloituneessa yhteiskunnassa ei enää kohdistu koko kulttuuriin vaan paneutuu yksittäisiin ilmiöihin, laajaa yleisökeskusteluakin aikaansaanut Richard Floridan teoria luovasta luokasta.

Raine Koskimaan artikkeli johdattaa digitaalisen kulttuurintutkimuksen käsitteen hahmottamiseen. Hän kuvaa digitaalisuuden käsitettä siirtymävaiheeksi, joka piankin ohitettaneen. Kun digitaalisuus läpäisee kulttuurin, ei sitä tarvitse erikseen mainita. Ei kodinkoneista puhuttaessakaan enää mainita erikseen, että ne toimivat sähköllä. Koskimaan artikkeli on tietyllä tavalla ohjelmallinen, sillä hän painottaa voimakkaasti pelien erityislaatuisuutta digitaalisen kulttuurin sisällä. Hän kehottaa kohdistamaan kulttuurintutkimuksellisen katseen pelikulttuuriin sekä perustamaan erityisen, peleihin keskittyvän tieteenalan, ludologian. Raija-Leena Loisan artikkeli on asiallinen johdanto frankfurtilaisen koulukunnan, erityisesti Theodor W. Adornon kulttuuriteollisuuden teoretisoinnin luonteeseen ja taustoihin. Vaikka hänen massakulttuurin logiikkaa käsittelevät ajatuksensa on kehitetty ennen 1960-lukua ja varsinaisen populaarikulttuurin ja kulttuuriteollisuuden räjähdysmäistä kasvua, ei niitä silti voida pitää täysin aikaansa sidottuina.

Tuija Saresma lähestyy feminististä kulttuurintutkimusta Eeva Jokisen tarjoaman perhemetaforan avulla, jolloin se näyttäytyy niin kulttuurintutkimuksen kuin feministisen tutkimuksenkin pikkusisarena. Tätä sisaruussuhdetta ja feministisesti painottuneen kulttuurintutkimuksen kehitystä ja näkökulmia Saresma analysoi tarjoamalla myös kiinnostavia ja valaisevia esimerkkejä erityisesti suomalaisesta tutkimuksesta. Joel Kuortti puolestaan perehdyttää lukijansa jälkikolonialistiseen kirjallisuudentutkimukseen. Hänen artikkelinsa käyttöarvoa kasvattaa aihepiirin erityissanaston esittely sekä kattava ja monipuolinen kirjallisuusluettelo. Samaa formaattia olisi voinut soveltaa myös muiden artikkelien kohdalla. Kirjallisuudentutkimuksen sisällä pysyttelee myös Urpo Kovala artikkelissaan reseptiotutkimuksesta.

Teoksen ensimmäinen osa tarjoaa hyviä, perusteellisia ja ansiokkaita oppija käsitehistoriallisia johdatuksia kulttuurintutkimuksen osa-alueisiin sekä keskeisten 


\section{TiINA MAHLAMÄKI}

teorioiden ja teoreetikkojen ajatuksiin. Tenttikirjana teokseen perehtyvä opiskelija saa melko hyvän kuvan siitä, mihin perinteeseen kulttuurintutkimus sijoittuu, mihin ideologioihin se sitoutuu ja minkälaisiin kysymyksiin siinä pyritään vastaamaan. Kulttuurintutkimus pitää kuitenkin sisällään niin moninaisia ulottuvuuksia, että täysin kattavana johdatuksena tätä ei voida pitää.

\section{KOKEMUKSIA JA KÄYTÄNTÖJÄ}

Artikkelikokoelman toinen osa, "Kokemuksia ja käytäntöjä", tarjoaa näkökulmia neljään tutkimusaiheeseen: taidekiistoihin, musiikkimuistoihin, faniuteen sekä uskontoon. Yrjö Heinosen artikkeli musiikkimuistoista osoittaa, miten aineiston määrä ei ole ratkaiseva vaan analyysin syvyys. Hän lähtee liikkeelle yhdestä "Leidit lavalla" -konserttikiertuetta käsittelevästä sanomalehtipakinasta ja etenee pakinan merkityksen ja tekstin omaelämäkerrallisuuden analyysin ohitse kohti musiikkimuistojen sukupolvi- ja kontekstisidonnaisuutta. Yksilön kokemusten avulla tutkijalla on pääsy yhteisöllisyyteen, tässä tapauksessa iskelmiin ikkunoina menneisiin ja nykyisiin sosiaalisiin todellisuuksiin, iskelmiin kansakunnan kätkettynä muistina. Vaikka tiettyihin musiikkiesityksiin kätkeytyvät merkitykset ja muistot ovat yksilöllisiä, jokaiselle ihmiselle ainutkertaisia, ovat ne samalla myös sosiaalisia ja jaettuja. Tällaisia konteksteja ovat vaikkapa Heinosen mainitsemat "yläasteaikainen ihastus", "ensimmäinen mökkijuhannus kavereitten kanssa" tai "teltan oviaukossa rockfestivaalien jälkeisenä aamuna". Suurelle osalle meistä nämä mainitut tai ainakin niille läheisten tilanteiden muistelu kiinnittyy johonkin tiettyyn tai joihinkin tiettyihin musiikkiesityksiin. Mutta meidän kaikkien päässä soivat eri biisit.

Irma Hirsjärven ja Urpo Kovalan yhteisartikkeli fanitutkimuksesta olisi vallan mainiosti sopinut myös teoksen alkupuoliskoon, sillä siinä esitellään faniuden käsitettä ja määritelmiä sekä fanitutkimuksen keskeisiä teorioita ja tutkimuksia sekä niiden kritiikkiä. Nuoren, vain vähän yli kymmenvuotiaan tutkimusalan esittelyn lisäksi pohditaan myös sen tulevaisuuden näkymiä. Fani- tai fandom-tutkimuksessa - ja tämä vaikuttaa ongelmalliselta kulttuurintutkimuksessa ylipäätään - on vaikea määritellä, mikä sen varsinainen kohde on tai mikä on tutkittavan faniuden kohde. Fanius itsessään on hyvin epäyhtenäinen alue, ihminen voi olla fani hyvin monilla eri tavoilla ja eri intensiteeteillä, ja kaikilla faneilla on eri-ikäisinä eri merkitykset faniudelleen sekä erilaiset faniuden toteuttamisen ja kokemisen tapansa - ja koko ajan ollaan kuitenkin tekemisissä yhteisöllisen ilmiön kanssa. Fanitutkimuksen kohdalla pitänee erityisen hyvin paikkansa se toteamus, että kulttuurintutkija on välttämättä osa tutkimuksensa kohdetta, sillä useat fandom-tutkijat ovat faneja itsekin. Myös itse kulttuurintutkimuksen kenttää on tarkasteltu faniuden näkökulmasta, jolloin tietyt johtavat teoreetikot näyttäytyvät faniensa näkökulmasta ihailun ja tunnustuksen kohteina.

Osion viimeisessä artikkelissa Teemu Taira osoittaa, miksi ja miten uskonto voi olla ja sen tulisi olla myös kulttuurintutkimuksen kohde. Hän pyrkii tässä kuten myös muissa teksteissään tuomaan esiin tapoja ja näkökulmia, joilla uskonnontutkimus voi hyötyä kulttuurintutkimuksesta ja päinvastoin. Uskonto ilmiönä on niin monimuo- 


\section{NäKÖKULMiA NYKYKULtTUURIN TUTKIMUKSEEN}

toinen ja muuttuva, että kulttuurintutkijan on vaikea hahmottaa tai lähestyä - tai edes löytää sitä - ilman uskontotieteen käsitteellisiä työkaluja, vertailevaa otetta ja etnografisia aineistoja. Uskonto ei ole pelkkää fundamentalismia tai uskonnollisia yhteisöjä, vaan pikemmin hyvin arkipäiväisiä ja tavallisia käytäntöjä. Uskontotiede tieteenalana taas kaipaa lisää kulttuurintutkimuksen poliittista, eettistä ja kriittistä asennetta. Taira on itse soveltanut tutkimuksissaan kontekstuaalista sekä artikulaatioteoreettista lähestymistapaa, jota hän pitää toimivana työkaluna myös uskonnon tutkimisessa, sillä uskonto (oppina, käytäntönä, retoriikkana jne.) kytkeytyy ja on sidoksissa aina välttämättä eri konteksteihin, kuten vaikkapa politiikkaan, talouteen, ideologioihin tai sosiaalisiin suhteisiin. Taira nostaa esiin myös tärkeän huomion uskonnosta yhtenä eron merkkinä yleisemmin käytettyjen rodun, luokan, etnisyyden ja sukupuolen lisäksi.

\section{MIHIN TÄSTÄ}

Artikkelikokoelman lopussa on laaja, kulttuurintutkimuksen keskeisen teoreetikon Lawrence Grossbergin diagnoosi kulttuurintutkimuksen paikasta, nykytilasta ja tulevaisuuden suunnista. Grossberg nostaa kulttuurintutkimuksen keskeisten käsitteiden, kontekstualismin ja artikulaation rinnalle tai ohi konjunktuurin käsitteen. Tällä hän tarkoittaa yhteiskuntamuodostumaa "kuvattuna säröileväksi ja ristiriitaiseksi, moninaisilla akseleilla, tasoilla ja asteikoilla, etsimässä jatkuvasti tilapäistä tasapainoa tai rakenteellista vakautta monenmoisten kamppailun ja neuvottelun käytäntöjen kautta" (s. 307). Konjunktuurien tutkiminen nouseekin siis yhdeksi, joskaan ei ainoaksi keskeiseksi kulttuurintutkimuksen tehtäväksi. Koska itse en ole kulttuurintutkimuksen sisäisiin keskusteluihin kovinkaan perehtynyt, olen taipuvainen yhtymään Grossbergin artikkelin yhteen alaotsikkoon: "Kuinka kulttuurintutkimuksesta tuli niin saamarin pitkästyttävää?” (S. 312.) Toki pitkästyttävyyden Grossberg määrittelee eri tavoin kuin minä. Vaikka artikkelissa tuodaankin hyvin esille erityisesti kulttuurintutkimuksessa vallitseva, mutta myös muille tieteenaloille tarpeellinen agenda, että tieteenalan on taukoamatta reflektoitava omaa paikkaansa analysoimissaan konteksteissa, voi sen kokonaisuuden avautuminen opiskelijalle olla vaivalloista. Toki tämän kuten muidenkin artikkelien ymmärtämistä helpottavat huomattavasti teoksen alun laajat yhteenvedot jokaisesta tekstistä.

Vaikka teos on kokonaisuutena on joiltain osin epätasainen ja epäyhtenäinen sekä paikoitellen melko vaikeasti kulttuurintutkimuksen ulkopuolelle sijoittuneelle avautuva, soveltuu se lupauksensa mukaisesti kulttuurintutkimuksen perusopintoihin ja lähitieteiden, kuten kulttuurien tutkimuksen alojen, aineopintoihin. Sitä voi suositella myös kulttuurintutkimuksellisesti orientoituneelle opinnäytteen tekijälle johdannoksi aihealueeseen ja johdatukseksi alkuperäislähteisiin. Tosin kulttuurintutkimuksen perusteisiin on ensin perehdyttävä jonkin toisen teoksen avulla. Tähän tarpeeseen teoksen ensisivulla annetaankin tutustumisen arvoisia kirjavinkkejä. Kulttuurintutkimus on haasteellinen tieteenala ja se tarjoaa myös kulttuurien tutkijoille tärkeitä asenteita, asemia ja painotuksia, joita tulisi tähänastista enemmän hyödyntää. 
Teoksen käytettävyys olisi kasvanut merkittävästi, jos siihen olisi liitetty asia- ja henkilöhakemisto, sillä monia teorioita, käsitteitä ja teoreetikoita käsitellään useammassa artikkelissa, hieman eri painotuksin.

Filosofian tohtori Tiina Mahlamäki on uskontotieteen tutkija ja arkistovastaava Turun yliopiston kulttuurien tutkimuksen laitoksella. 